\title{
Mud2Metal: Lessons Learned on the Path for Complete Utilization of Bauxite Residue Through Industrial Symbiosis
}

\author{
Efthymios Balomenos $^{1,2}$ (1) Panagiotis Davris $^{2} \cdot$ Yiannis Pontikes $^{3} \cdot$ \\ Dimitrios Panias ${ }^{2}$
}

Published online: 28 November 2016

(C) The Minerals, Metals \& Materials Society (TMS) 2016

\begin{abstract}
A new concept for a holistic exploitation of the bauxite residue (BR) is presented, where a multitude of niche and bulk application products are produced, leading to a near zero-waste, financially viable, and environmentally benign process. Based on the combination of recent research results, the "Mud2Metal" conceptual flow sheet was developed in order to produce added value products rationalizing BR sustainable valorization. The Mud2Metal flow sheet is analyzed technologically, environmentally, and economically, addressing the challenges and the effects of each processing step, for the case of the Greek BR. The Mud2Metal flow sheet is focused on the selective removal of rare earth elements, the subsequent production of pig iron for the iron and steel industry, and the valorization of the residual slag's engineered mineral matrix into a variety of building materials. Based on further technological innovation and flow sheet integration/optimization, the plant operation could become economically profitable for the alumina industry, environmentally benign, and socially acceptable; in one word: sustainable.
\end{abstract}

Keywords Bauxite residue $\cdot$ Red mud $\cdot$ Zero-waste $\cdot$ REE . Scandium $\cdot$ Slag valorization $\cdot$ Iron

The contributing editor for this article was Bernd Friedrich.

Efthymios Balomenos

Efthymios.BALOMENOS-EXTERNAL@alhellas.gr

Aluminium of Greece, Ag. Nikolaos Plant, Viotia, Greece

2 School of Mining and Metallurgical Engineering, NTUA, 15780 Zografou, Greece

3 Department of Materials Engineering, KU Leuven, 3001 Leuven, Belgium

\section{Introduction}

During alumina production from bauxite ore through the Bayer process, a digestion residue is produced in the form of a red slurry, often termed as "red mud." On dewatering, this by-product amounts to an almost 1:1 mass ratio with the alumina produced and is called bauxite residue (BR) since it embodies the undissolved portion of the processed bauxite ore [1]. A vast amount of research effort is spent on the effective utilization of BR [2-4]. Although numerous projects and research efforts attempt to utilize BR as a source for the production of a raw material (e.g., blast furnace for pig iron production) or to utilize it as a feedstock in another industry (i.e., raw meal in cement kilns $[5,6])$, real-life cases of industrial utilization of BR are currently scarce and can only be applied on a small fraction of the produced BR [71]. This is largely because most solutions proposed aim at using $\mathrm{BR}$ as a raw material substitute in a single established industrial process leading to uneconomic or potentially disruptive processes. Direct utilization options for BR in large-scale, low-cost applications like clay-ceramics production or soil additives have been developed for more than 20 years and yet have never been applied. Figure 1 illustrates examples of BR utilization options investigated at the Aluminium of Greece refinery (AoG) in collaboration with a number of institutions including National Technical University of Athens (NTUA), University of Patras, and Aristotle University of Thessaloniki. Efforts have been primarily directed for the production of high-volume building materials, i.e., aggregates, ceramics, cement, followed by higher added value applications, i.e., glass-ceramics and catalysis [8]. The aftermath of this intense effort is didactic: currently only about $10,000 \mathrm{t}$ of the Greek BR is used as a raw material for clinker cement production. Other processes although 
Fig. 1 Examples of developed and tested BR utilization options in AoG since 1991
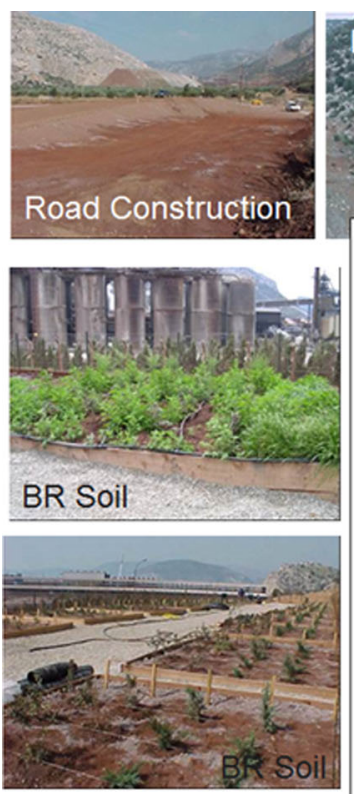

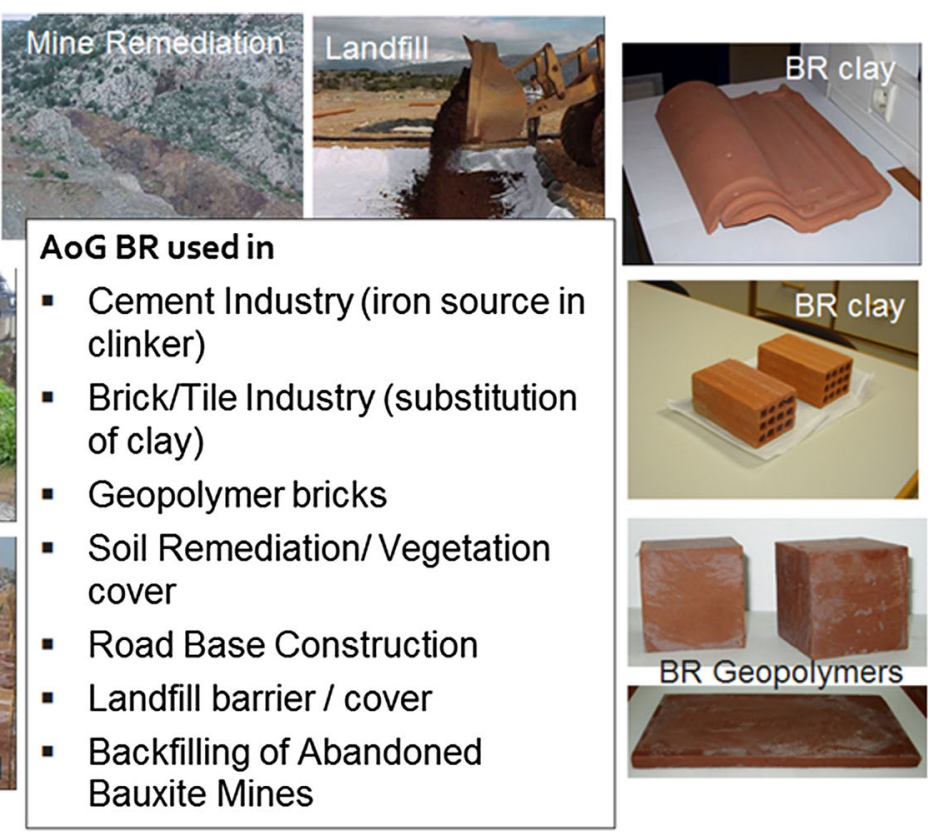

being technologically robust, have yet to prove financially viable.

Indeed, using BR as an iron (or alumina) source in clinker cement production is perhaps the most widespread BR utilization option varying between 500,000 and 1,500,000 t per year worldwide [7]. This amounts to less than $1 \%$ of BR global production, as this practice is challenged by various factors ranging from transport cost and logistics to limitations imposed by processing chemistry, leading eventually to small amounts of BR in the raw meal of the clinker.

Exploiting BR as a mineral source for iron (up to $48 \mathrm{wt} \%$ iron oxide in the case of Greek BR) cannot be as economical as an iron ore concentrate (typically above $60 \mathrm{wt} \%$ iron oxide), and also direct feeding of BR in a blast furnace is problematic due to the high soda content. Therefore, BR is used in small amounts as iron ore substitute.

The Greek BR stream, delivered as filtercake from filter presses since 2012, contains (Fig. 2) significant amounts of iron, aluminum, silicon, calcium, and titanium oxides as well as smaller concentrations of critical and/or industrially important elements such as rare earth elements (REEs) (mainly Ce, La, Sc, Y, Nd), V, Cr, and others. Particularly the high scandium content (120-135 mg/kg in Greek BR) makes BR a valuable secondary resource [9]. However, comparing BR with a REE mineral deposit of similar grade $[0.14 \%$ Total rare earth oxides (TREO) in the case of Greek BR] is erroneous as BR cannot be beneficiated into higher grade concentrates (i.e., 15-30\% TREO or higher), typically used in the REE industry, and which can be economically exploited by established processes [10]. REE concentration in BR produced has been found to be fairly constant with only $8 \%$ variation over a period of 15 years indicating that $\mathrm{BR}$ can be considered a reliable secondary $\mathrm{REE}$ resource [11].

As of today, no single BR utilization route has been found to be a stand-alone solution for $100 \%$ of all BRs produced in an alumina refinery, as BR utilization in a different industry is either technically complicated or financially non-viable. Therefore, the idea of combining more than one solution in an integrated processing flow sheet is being pursued, producing products or raw materials for more than one industry and thus securing financial viability. Conceptually, this can be seen as an attempt to form the core of industrial symbiosis hubs.

In the recent past, the ENEXAL RTD project [12] successfully transformed AoG's BR into pig iron and mineral wool in a near zero-waste process. The process would be financially viable or even profitable as long as both products were sold. But since the mineral wool market in Greece is limited to a size of 60,000-120,000 $\mathrm{t}$ (and transportation of this light material over longer distances would be associated with substantial costs), the process could not be applied to $100 \%$ of the annual AoG's BR production. Moreover, REE recovery was not foreseen in that process. Hence current efforts are directed toward technological innovations that will allow multiple high added value products to be produced under a single and flexible processing flow sheet, as shown in Fig. 3. Under this approach, the multitude of products secures both the financial viability of the flow sheet as well as the complete utilization (near zero waste) of the BR produced by the alumina industry. Iron alloy and cement are two products with huge market applications which can absorb the 


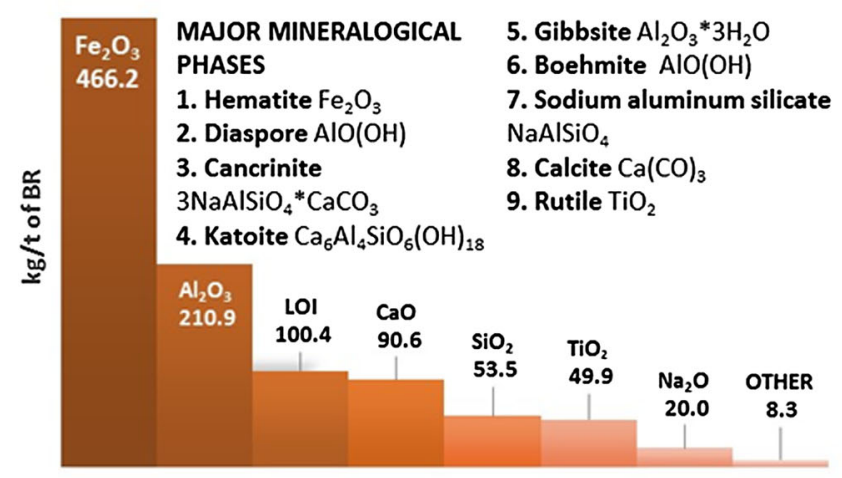

Major BR Components

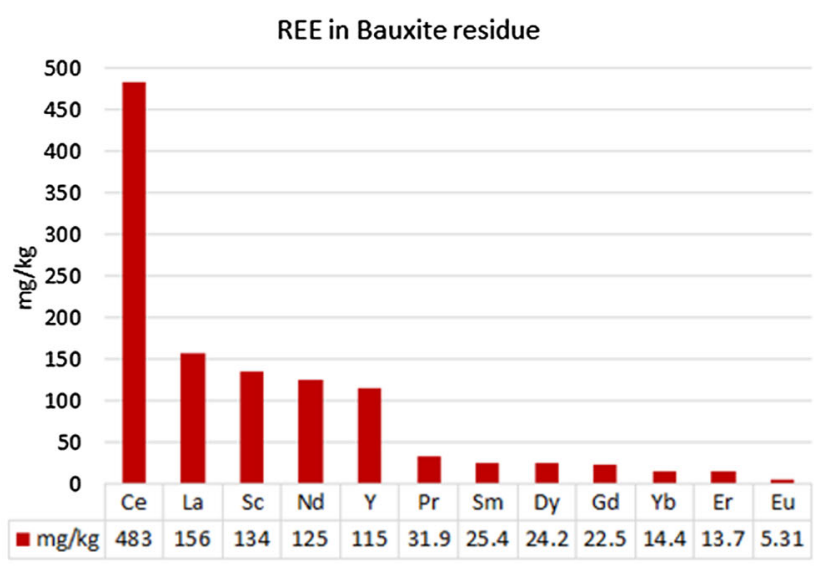

Fig. 2 Mineralogy and metal concentration of base and rare earths elements (wet chemical analysis). Loss of ignition (LOI), derives as steam and $\mathrm{CO}_{2}$ from mineral decomposition up to $1000{ }^{\circ} \mathrm{C}$

Fig. 3 Mud2Metal flow sheet: from BR "waste" to various high added value products

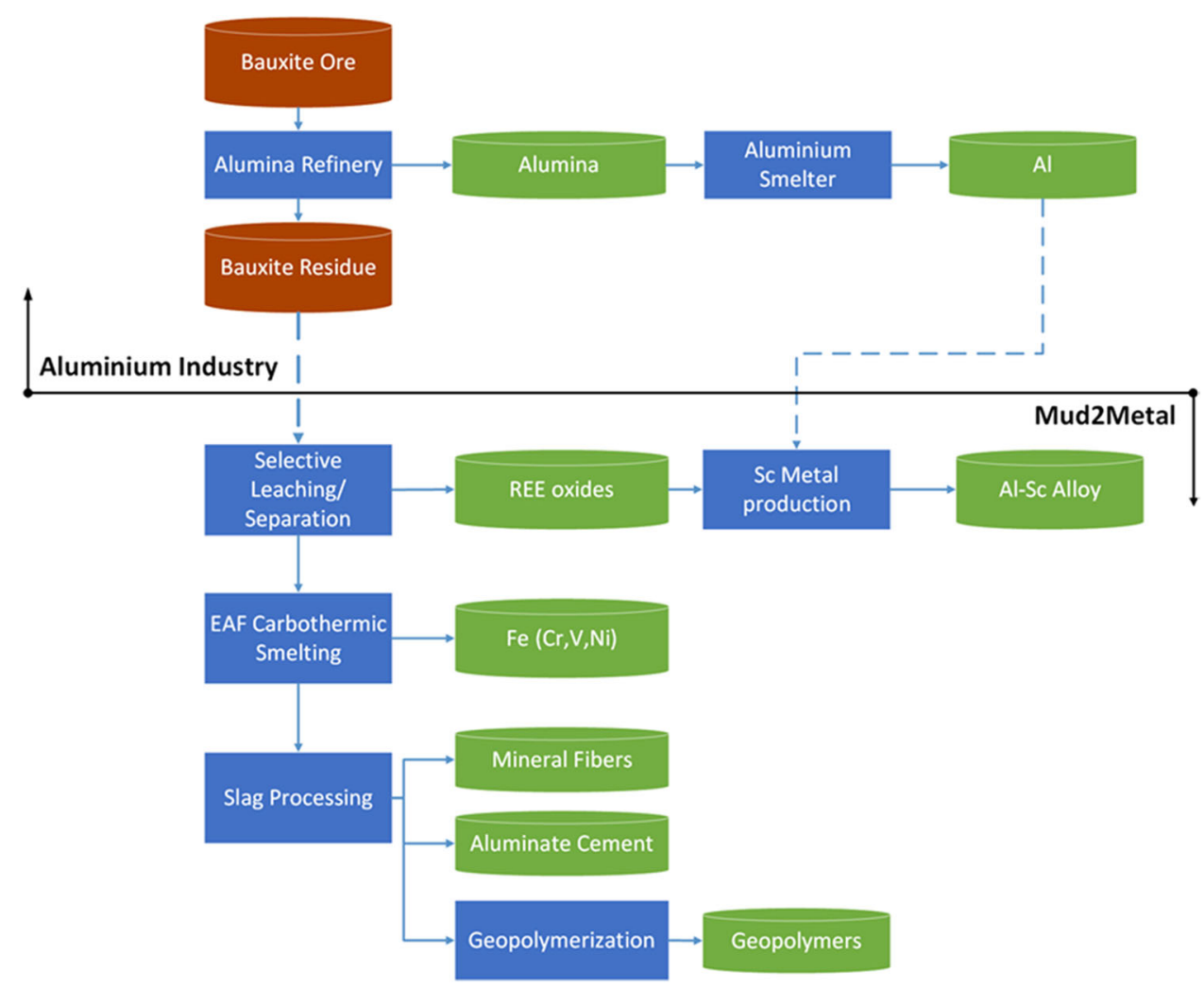

majority of the BR volume. In addition, products for niche market applications like REE compounds, Al-Sc master alloy, mineral fiber products, and specialty cements, have more limited markets in terms of product volumes but significantly higher product values, resulting in strengthening the financial aspect of the flow sheet and mitigating the risk.

The key processing steps of this flow sheet (Fig. 3) are presented in the following sections. It should be noted that this case study is based solely on the Greek BR which has a relatively high iron and REE/Sc content. Different flow sheets would be required for different BRs, and several flow sheets have been proposed in the past. In most of the reviewed cases [3, 4], a combination of sequential pyrometallurgical and hydrometallurgical processing is proposed for recovering iron, alumina, titanium, and REE content. As shown in the present paper, the key barrier for any combination of technological solution is the economics of the flow sheet. Hence there is no single solution that can be universally used in the BR valorization world, but rather each solution has to be tailored for each refinery. 


\section{Hydrometallurgical Pre-treatment for REE Recovery}

Bauxite residue's potential as a secondary resource for REE production receives escalating attention [4, 9, 13-15] since REEs are essential materials for applying greener technology [16]. REEs have been labeled as highly critical metals in terms of supply risk and energy-economic importance in Europe and the United States [17, 18]. Investigations have shown that Greek BR contains $\sim 1 \mathrm{~kg}$ REEs/t (incl. Sc) [19-21] and that this concentration is fairly constant, with a variation of only $8 \%$ over several years, whereas the enrichment factor of the rare earths in BR compared to bauxite ore is about a factor of two. The values of these REEs as separated REE oxides are presented in Table 1, where the economic dominance of scandium is clearly observed. Despite the recent deflation of REE prices, back to the levels of the 2010-2011 markets, scandium prices remain high with increasing trends [22].

Scandium is an element of high technical and economic importance mainly because of its applications in high performance Al-Sc alloys [26] and in emerging solid oxide fuel cell (SOFC) technology [27, 28]. Scandia-stabilized zirconia ( $\mathrm{ScSZ}$ ) is found to be an excellent solid electrolyte for SOFCs while Al-Sc alloys represent a new generation of high performance alloys with superior properties over all other aluminum alloys. In nature, scandium is rarely concentrated and remains widely dispersed in the lithosphere as it lacks affinity to combine with the common oreforming anions. Therefore, its production is mostly based on the by-product of the titanium and uranium industries [9]. The global supply of scandium is currently estimated to be about $10-15 \mathrm{t}$ per year [22], and the price for scandium oxide with $99.9 \%$ purity has risen in recent years from \$US $1500 / \mathrm{kg}$ to over $\$$ US $4500 / \mathrm{kg}$. The low-volume and high-priced Sc production has hampered the largescale applications for $\mathrm{Al}-\mathrm{Sc}$ alloys particularly in the aerospace industry. A viable BR valorization for scandium could hold the key for increasing the global supply of scandium and regulating its prices at levels where mass scale application of Al-Sc alloy can take place.

REE extraction from BR and particularly scandium has been studied either by direct hydrometallurgical treatment (selective leaching) or by combined pyro-hydrometallurgical processes (smelting/roasting followed by slag leaching) $[3,29]$. Studies on selective leaching REE from BR with dilute mineral acids such as nitric, hydrochloric, and sulfuric acid have been extensively conducted with further purification/enrichment of the pregnant solution by means of ion exchange or solvent extraction [19, 30-34]. Also sulfurous acid leaching [35], carbonization [36], bioleaching [37], and ionic liquids [20,38] have provided significant results for selective leaching REE. An outline on leaching REE from BR and leaching the resulting slag after BR smelting is presented in Table 2.

In the present Mud2Metal flow sheet (Fig. 3), REEs were chosen to be extracted selectively from the Greek BR stream prior to pyrometallurgical processing. Selectivity in leaching, especially against iron is crucial for producing a low impurity pregnant liquid solution (PLS) stream from which REE and Sc can be economically extracted with established solvent extraction or ion-exchange technologies, avoiding Fe interferences. Such processes have been successfully studied for the case of the Greek BR using a variety of leaching agents [19, 20, 30, 31, 38]. Leaching performance for the Greek BR in terms of increasing selectivity of $\mathrm{Sc}$ against $\mathrm{Fe}$ follows the trend of
Table 1 REE values in Greek BR

\begin{tabular}{llclcr}
\hline $\mathrm{REE}$ oxide & Greek BR & Prices & Price year \& ref. & \multicolumn{2}{c}{ Value in $1000 \mathrm{~kg}$ of Greek BR } \\
\cline { 5 - 6 } & $\mathrm{g} / \mathrm{kg}$ & $\$ / \mathrm{kg}$ & & $\$$ & $(\%)$ \\
\hline $\mathrm{Sc}_{2} \mathrm{O}_{3}$ & 0.21 & 3700 & $2013[22]$ & 777.00 & 05 \\
$\mathrm{Y}_{2} \mathrm{O}_{3}$ & 0.15 & 8 & $2015[22]$ & 1.20 & 0 \\
$\mathrm{La}_{2} \mathrm{O}_{3}$ & 0.18 & 2 & $2015[22]$ & 0.36 & 0 \\
$\mathrm{CeO}_{2}$ & 0.59 & 2 & $2015[22]$ & 1.18 & 1 \\
$\mathrm{Pr}_{2} \mathrm{O}_{3}$ & 0.04 & 119 & $2014[23]$ & 4.76 & 1 \\
$\mathrm{Nd}_{2} \mathrm{O}_{3}$ & 0.15 & 65.9 & $2014[23]$ & 9.89 & 0 \\
$\mathrm{Sm}_{2} \mathrm{O}_{3}$ & 0.03 & 15.6 & $2013[24]$ & 0.47 & 1 \\
$\mathrm{Eu}_{2} \mathrm{O}_{3}$ & 0.01 & 787 & $2014[23]$ & 7.87 & 0 \\
$\mathrm{Gd}_{2} \mathrm{O}_{3}$ & 0.03 & 12 & $2016[25]$ & 1.50 & 1 \\
$\mathrm{Dy}_{2} \mathrm{O}_{3}$ & 0.03 & 379.6 & $2014[23]$ & 11.39 & 0 \\
$\mathrm{Er}_{2} \mathrm{O}_{3}$ & 0.02 & 53 & $2016[25]$ & 3.20 & 100 \\
$\mathrm{Total}$ & 1.42 & & & 818.81 & 0 \\
\hline
\end{tabular}

99.0-99.9\% purity for all oxides 
Table 2 General remarks on REE leaching from BR and from slag after BR smelting/roasting

\begin{tabular}{ll}
\hline Potential & Main issues addressed \\
\hline BR direct leaching & \\
REE selectivity against $\mathrm{Fe}, \mathrm{Ti}$, and in some cases $\mathrm{Si}$ & $\mathrm{Sc}$ selectivity against iron is limited to about $45-55 \%$ \\
$\mathrm{Na}, \mathrm{Ca}$ removal (neutralization of $\mathrm{BR}$ ) & $\begin{array}{l}\text { No selectivity against } \mathrm{Ca}, \mathrm{Na} \text {, and a part of } \mathrm{Al} \\
\text { Upgrade in iron content of the resulting residue } \\
\text { Acid residues may interfere in the pyrometallurgical extraction of iron (depending on acid } \\
\text { used) }\end{array}$ \\
$\begin{array}{l}\text { Slag leaching after BR smelting/roasting } \\
\text { High REE/Sc recoveries can be obtained }\end{array}$ & $\begin{array}{c}\text { Intense acidic conditions needed due to mineral acid resistant phases such as perovskite, } \\
\text { formed during pyrometallurgical treatment of BR }\end{array}$ \\
$\begin{array}{l}\text { Slightly higher REE concentration from } \mathrm{BR} \\
\text { pow concentration of Fe into solution }\end{array}$ & $\begin{array}{c}\text { particle size are needed (in case of smelting) } \\
\text { Potential Ti (and } \mathrm{Al} \text { ) co-recovery }\end{array}$
\end{tabular}

$\mathrm{HNO}_{3}>\mathrm{H}_{2} \mathrm{SO}_{4}>\mathrm{HCl}$ [31]. Recovery rate of Sc during selective leaching is limited in the range of $20-50 \%$ with Fe dissolution $<5 \%$, whereas the rest of the REE can be recovered with more than $80 \%$ efficiency, indicating the different mineral associations between REE and Sc that is found in BR $[19,38]$. In most cases, selective dissolution against $\mathrm{Fe}, \mathrm{Ti}, \mathrm{Al}$, and $\mathrm{Si}$ is achieved but not against $\mathrm{Ca}$ and $\mathrm{Na}$ which are easily dissolved during the process. Despite successful selectivity in leaching, the PLS generated contains REE ions in the range of $1-10 \mathrm{mg} / \mathrm{L}$, while $\mathrm{Fe}$ and other ions are in the range of several thousand $\mathrm{mg} / \mathrm{L}$ $[19,30]$. Low concentration of REE in PLS is the outcome of combining low REE content feeding material and applying low pulp density (\%w/v) during leaching. Extraction of REE from the generated dilute solutions is the key processing step which defines the economics of the process. Conventional $\mathrm{S}-\mathrm{X}$ methods require far too many processing steps, and therefore several groups have investigated selective methods and extractants to be applied in such a process [30, 33, 34, 39]. Ionic liquid HbetTf2 $\mathrm{N}$ [38] is able to generate a concentrated acidic PLS after BR leaching, increasing by many folds the concentration of $\operatorname{REE}(\sim 140 \mathrm{mg} / \mathrm{L})$ and $\mathrm{Sc}(\sim 45 \mathrm{mg} / \mathrm{L})$, providing an advantage on PLS purification using the above-mentioned methods. Furthermore, the resulting solid residue obtained after selective recovery of REE is concentrated in Fe and depleted from $\mathrm{Na}$ and $\mathrm{Ca}$ (Table 3), thus making it more suitable for its pyrometallurgical treatment for iron recovery and slag valorization as will be discussed in the following sections.
The economic impact of extracting Sc and REE from the Greek BR can be very significant as

1. the REE content in the annual Greek BR production amounts to $10 \%$ of the annual European REE imports (8000 t per year) [17], taking into account mainly the REEs with the higher concentration in $\mathrm{BR}(\mathrm{Y}, \mathrm{La}, \mathrm{Ce}$, $\mathrm{Nd}$ );

2. the scandium content in BR $(135 \mathrm{mg} / \mathrm{kg})$ is considered a financially exploitable concentration [9]; and

3. the leaching residue generated is rich in iron and aluminum oxides, making it more suitable for use as iron ore substitute in blast furnace or iron and alumina source in cement kilns [5, 40].

\section{Pyrometallurgical Treatment of BR for Iron Recovery}

Iron recovery from BR has been thoroughly investigated, and the developed technologies have been reviewed in several publications [3, 41-43]. The pyrometallurgical recovery of iron from the BR valorises approximately half of the Greek BR stream and at the same time alters the properties of the remaining material (slag) in such a way that it can be further processed, resulting in a zero solid/ liquid waste process. Solid state reduction roasting [44-46] and reductive smelting [42, 47] are perhaps the most promising ones for producing either high-grade magnetite $\left(\mathrm{Fe}_{3} \mathrm{O}_{4}\right)$ or metallic $\mathrm{Fe}$. Through carbothermic reduction

Table 3 Typical analysis of leaching residue obtained in NTUA after selective extraction of REE, Ca, Na, and moderate Al extraction [38]

\begin{tabular}{lllllll}
\hline$\%$ wt & $\mathrm{Fe}_{2} \mathrm{O}_{3}$ & $\mathrm{Al}_{2} \mathrm{O}_{3}$ & $\mathrm{TiO}_{2}$ & $\mathrm{SiO}_{2}$ & $\mathrm{CaO}$ & $\mathrm{Na}_{2} \mathrm{O}$ \\
\hline BR & 42.6 & 25.1 & 5.0 & 5.3 & 9.1 & 2.0 \\
Residue after pre-treatment & 56.1 & 12.3 & 7.5 & 6.5 & 0.1 & - \\
\hline
\end{tabular}


smelting using an electric arc furnace (EAF), the iron content of BR can be extracted as pig iron and sold as steel scrap substitute (price 300-EUR/t) to the secondary steel industry. BR trace elements like $\mathrm{V}, \mathrm{Cr}$, and $\mathrm{Ni}$, which are of great value to the iron/steel industry, are collected in the produced melting iron phase. The EAF carbothermic smelting technology was developed in the EC-funded ENEXAL project [12] (Fig. 4), which resulted in pig iron metal product the composition of which is presented in Table 4. The pig iron produced was suitable for the secondary steel industry as a $15 \mathrm{wt} \%$ scrap substitute in EAF processing. Larger BR pig iron utilization as scrap substitute would be disruptive to steel mill operations, as the minor elements of the BR pig iron $(\mathrm{Cr}, \mathrm{V}, \mathrm{S}, \mathrm{P} \ldots)$ would produce steel outside of the required specifications for typical applications like steel rebars. However, given the size of the iron and steel market, the secondary steel industry could absorb all the BR pig iron even at low-scrap substitute rates.

The ENEXAL process for the BR treatment resulted in a process with $32 \%$ exergy utilization efficiency [1] and improved the overall exergy utilization efficiency of the alumina plant by 14 percentile points. Yet if-as is the case in Greece-coal-based electricity is used to power the EAF smelting, then the exergy efficiency of the BR treatment is halved $(16 \%)$, as electricity from non-renewable sources is an exergy-expensive resource. In addition, as electricity is an expensive commodity, the total operational cost of the ENEXAL process is high (electricity cost accounts for $33 \%$ of the total cost) rendering the process marginally profitable.

With further optimization and technological innovation of the iron production process, one could control the presence of secondary elements in the alloy and produce directly cast iron alloys (i.e., gray cast iron) which are sold at significantly higher prices (i.e., 1000-1300 EUR/t).

\section{Slag Engineering for Building Products}

The carbothermic smelting of BR can utilize up to $60 \%$ of the total weight of the BR, leaving behind an $\mathrm{Al}, \mathrm{Ca}, \mathrm{Si}$ rich slag phase, an indicative chemical composition of which is presented in Table 5. The valorization of this material is essential in creating both an economically and environmentally viable BR treatment process. The slag
Fig. 4 ENEXAL flow sheet for $1 \mathrm{t}$ of BR processing in dusttreating EAF (batch processing trials, BR filtercake dried to below $2 \%$ in static bed dryer, dust collected in the bag filters has similar composition with the feed and can be recycled in the EAF) [6]
Table 4 Iron alloy composition

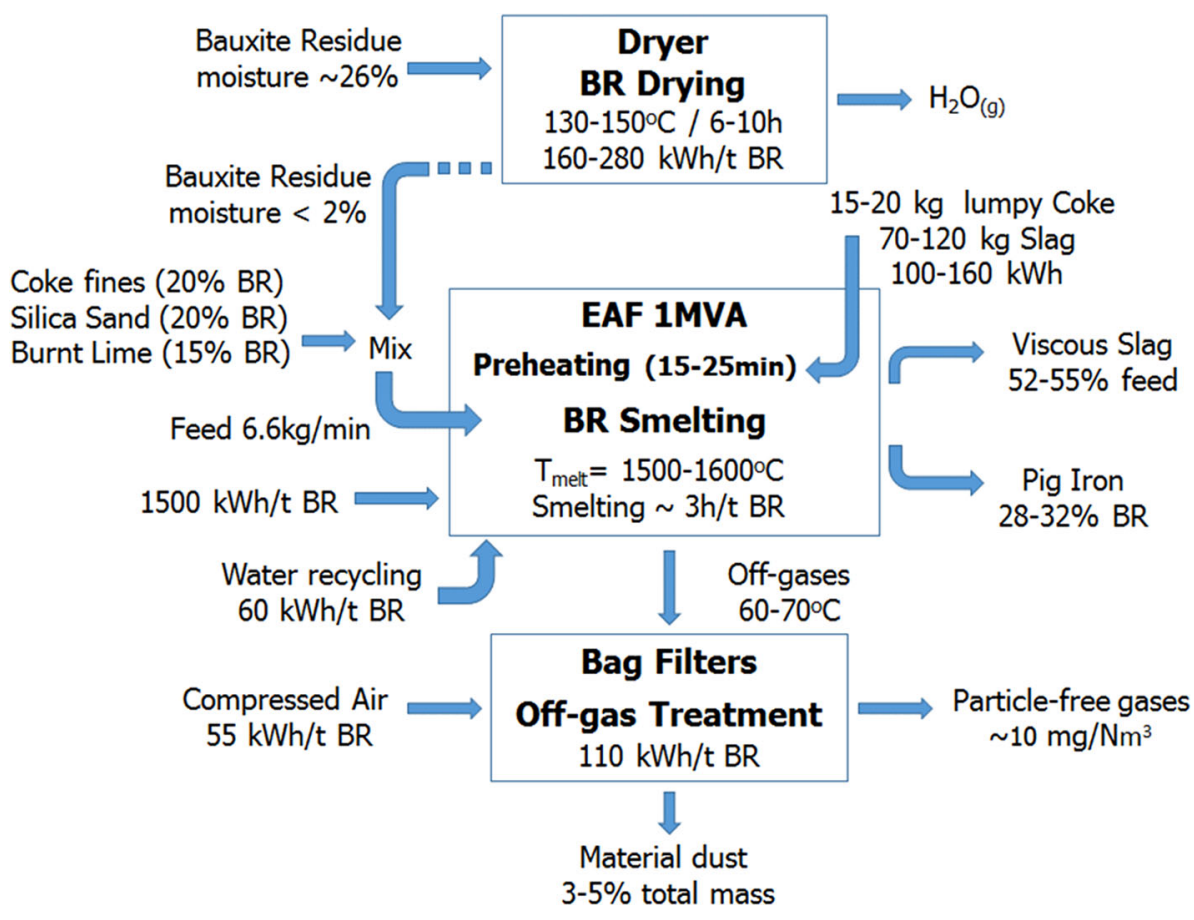

\begin{tabular}{lllllllllll}
\hline Element $(\%)$ & $\mathrm{Fe}$ & $\mathrm{C}$ & $\mathrm{Mn}$ & $\mathrm{Si}$ & $\mathrm{P}$ & $\mathrm{S}$ & $\mathrm{Ni}$ & $\mathrm{Cr}$ & $\mathrm{V}$ & $\mathrm{Cu}$ \\
\hline ENEXAL BR pig iron & 92.30 & 4.25 & 0.09 & 1.89 & 0.22 & 0.05 & 0.21 & 0.57 & 0.41 & - \\
Average steel scrap & 98.56 & 0.09 & 0.06 & 0.01 & 0.02 & 0.06 & 0.12 & 0.11 & 0.01 & 0.37 \\
Gray cast iron alloy & 92.78 & 3.40 & 0.5 & 1.80 & 0.20 & 0.07 & - & 0.35 & 0.15 & - \\
\hline
\end{tabular}


Table 5 Slag products' composition

\begin{tabular}{llllllll}
\hline$\%$ wt & $\mathrm{Al}_{2} \mathrm{O}_{3}$ & $\mathrm{CaO}$ & $\mathrm{MgO}$ & $\mathrm{SiO}_{2}$ & $\mathrm{TiO}_{2}$ & $\mathrm{FeO}$ & $\mathrm{Na}_{2} \mathrm{O}$ \\
\hline ENEXAL BR slag & 33.5 & 22.5 & 7.6 & 25.0 & 5.4 & 1.0 & 1.5 \\
Typical blast furnace slag & $7-16$ & $32-45$ & $5-15$ & $32-42$ & - & $0.1-1.5$ & - \\
Calcium aluminate cement & $36-42$ & $36-42$ & 0.1 & $3-8$ & $<2$ & $12-20$ & 0.1 \\
Typical slag wool products & $5-16$ & $20-43$ & $4-14$ & $38-52$ & $0.3-1$ & $0-5$ & $0-1$ \\
Refractory ceramic fibers & $35-51$ & $<1$ & $<1$ & $47-54$ & $0-20$ & $0-1$ & $<1$ \\
\hline
\end{tabular}

produced in comparison to the initial BR would be essentially free of moisture and chromium content, thus removing key technological barriers for its use in the cement industry (also approximately half the soda content of the BR is removed in the gaseous phase and is found condensed at the EAF's bag filters). This is a bulk, relatively low-value application which can absorb all the slag produced, ensuring a zero-waste process. In addition, based on its composition and especially its high alumina content, with appropriate hot or cold engineering, this slag could also be used as a raw material for higher added value products like mineral wool, aluminate cements, and geopolymers [48-50]. Such products have much more limited markets, which could absorb a small portion of the BR slag, but would help strengthen the economic aspects of the process.

In the ENEXAL project, the production of mineral wool products from the slag of the BR using EAF (Fig. 5) was demonstrated [12]. The wool produced had a thermal conductivity coefficient of $\lambda=0034 \mathrm{~W} / \mathrm{mK}$ (UNI EN 12667), similar to the market insulation product, and superior mechanical resistance due to its unique chemical composition: high $\mathrm{Al}_{2} \mathrm{O}_{3}$ and $\mathrm{TiO}_{2}$ context in comparison to typical products. Given that $85 \%$ of the energy in mineral wool production is associated with the initial melting of the mineral raw materials, in situ co-production of mineral wool during the carbothermic reduction of BR results in both a significant environmental and economic advantage for the industry.

Apart from the cement industry, BR has been used directly in geopolymer development [49]. Geopolymerization is a rapidly developing and innovative technology
[51], which utilizes solid aluminosilicate materials to produce a wide range of revolutionary materials, i.e., "geopolymers," which can further add to the range of added value BR slag products. Despite the number of studies concerning the use of BR as an aluminosilicate source for developing geopolymers, BR is limited as an aluminosilicate source for geopolymerization because in sodium hydroxide solutions only a small portion of its aluminosilicate phases can be dissolved. Therefore, in all cases, BR was used either as filler in geopolymers produced from other aluminosilicate sources, such as fly ash, rice husk ash, metakaolin, and slags [52], or after thermal processing [53-55].

In contrast, the produced BR slag from the Mud2Metal flow sheet would be effectively dissolved in sodium hydroxide solutions as it is an amorphous aluminosilicate matrix, the composition of which can be regulated through appropriate flux additions, to produce optimum geopolymer precursors. Additionally, alumina refineries have access to caustic soda at competitive price; thus the production cost can be suppressed. Moreover, it is possible that streams from the process itself can be utilized [56].

\section{Economic aspects}

The most crucial and defining aspect for the application of an integrated processing flow sheet like the one described in this work is its financial viability. An indicative production scenario is shown schematically in Fig. 6, where REE and iron production are based on the production

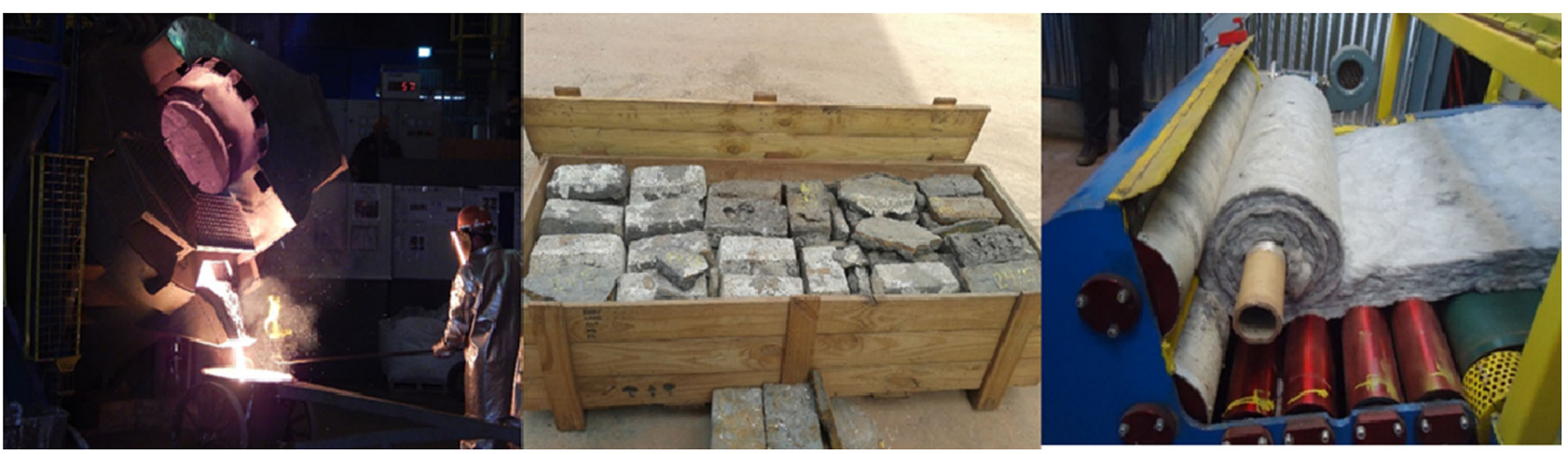

Fig. 5 Smelting of BR for producing pig iron and mineral wool 


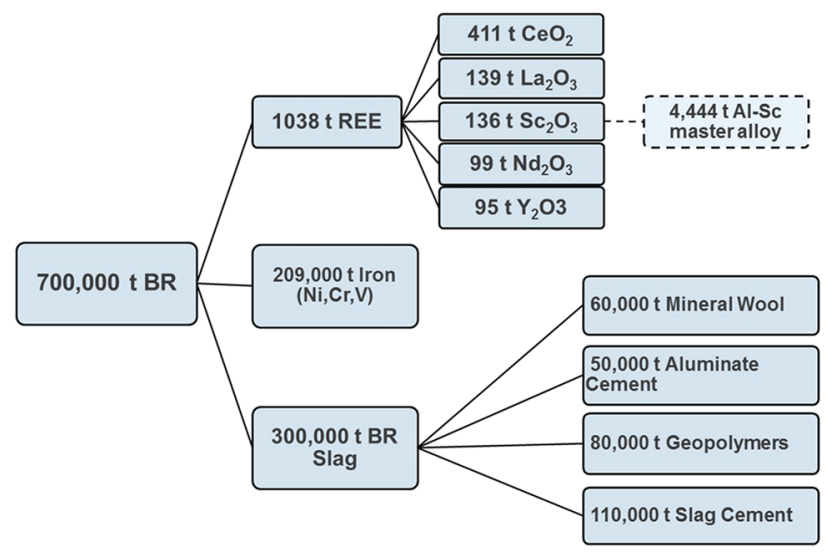

Fig. 6 Indicative products to be generated annually from Greek BR

efficiencies set out as $>85$ and $>95 \%$, respectively, while the slag products are chosen arbitrarily based on respective market sizes, product transport limitations, and competition. Usual production capacity for mineral wool plants is between 60,000 and $120,000 \mathrm{t}$ per year and for aluminate cement plants between 40,000 and 120,000 t per year.

Table 6 presents the prices of the various products that can be produced through the proposed flow sheet along with a first estimation of the relative processing costs (OPEX) based on the results and experience from pilot plant studies $[12,30]$. In accordance with the results, the operational cost for the EAF carbothermic smelting of BR and the slag processing for mineral wool production is 320 EUR/t of BR. Similarly, the operational costs of the developed process for Sc/REE selective extraction from BR are expected to be about $150 \mathrm{EUR} / \mathrm{t}$ of BR, for producing separate oxides of up to $95 \%$ purity. Further refining of such oxides to produce $99.99 \%$ grades would approximately double or even triple the above-mentioned processing cost. The slag geopolymerization costs are estimated at $56 \mathrm{EUR} / \mathrm{t}$ of product produced. Based on these figures and the current market prices, two financial scenarios to evaluate the operational margin of the flow sheet are made. The "optimistic" scenario considers the achievement of all technological objectives, producing cast iron (1000 EUR/t), a 99.0\% scandium oxide (sold between 500 and $1000 \mathrm{EUR} / \mathrm{kg}$ ), high-quality mineral wool (800 EUR/t), alumina cement (500 EUR/t), geopolymer composite building products (200 EUR/t), and slag cement (20 EUR/t). The pessimistic scenario assumes that only pig iron suitable for steel scrap substitute (300 EUR/t), a lowpurity scandium oxide concentrate (assumed to be sold at $500 \mathrm{EUR} / \mathrm{kg}$ ), lower-quality mineral wool (600 EUR/t), and aluminate cement additives (300 EUR/t) are produced. No geopolymer products are sold, and the remainder slag is used as cement meal or aggregates producing no net revenues for the alumina industry. In both the scenarios, the other REEs are sold as mixed REE oxides concentrate (6-8 EUR/kg). As shown in Fig. 7, the optimistic scenario results in a 140 million EUR annual operational margin (total revenues minus OPEX), while the pessimistic scenario yields 112 million EUR annual negative operational margin.

The Mud2Metal flow sheet could provide a zero-waste valorization solution for the $\mathrm{BR}$, which can be even made

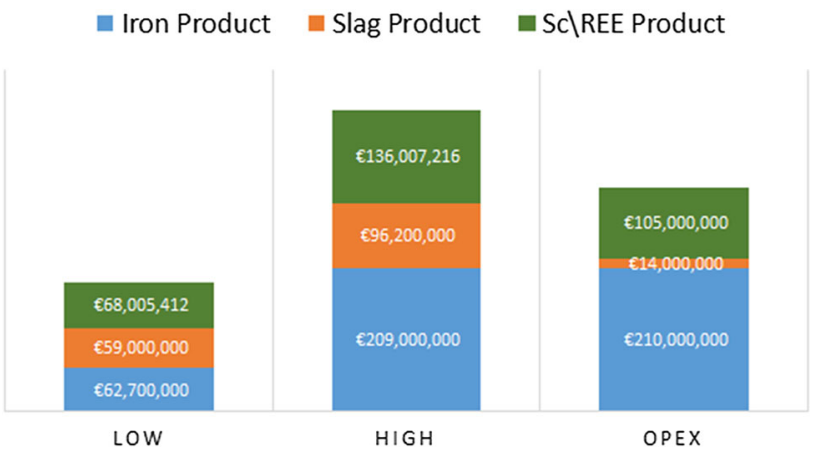

Fig. 7 Expected revenues under the two extreme scenarios of the Mud2Metal flow sheet compared to a projected OPEX, which for the purpose of this exercise is considered to be invariant in both cases

Table 6 Economics of BR processing annually

\begin{tabular}{|c|c|c|c|}
\hline Product & Amount produced $(\mathrm{t})$ & Market price $(E U R / t)$ & OPEX (million EUR) \\
\hline \multicolumn{4}{|l|}{ Iron product $(209,000 \mathrm{t}$ per annum $)$} \\
\hline Iron product & 209,000 & $300-1000$ & 210 \\
\hline \multicolumn{4}{|l|}{ Slag products $(300,000 \mathrm{t}$ per annum) } \\
\hline BR mineral wool & 60,000 & $600-800$ & 14 \\
\hline BR aluminate cements & 50,000 & $300-600$ & \\
\hline BR geopolymers & 80,000 & $100-200$ & \\
\hline BR slag cement/raw material for industry & 110,000 & $0-20$ & \\
\hline \multicolumn{4}{|l|}{ REE products (1038 t per annum) } \\
\hline $\mathrm{Sc}_{2} \mathrm{O}_{3}(99 \%)$ & 136 & $500-1000$ & 105 \\
\hline Mixed REO concentrate & 902 & $6-8$ & \\
\hline
\end{tabular}




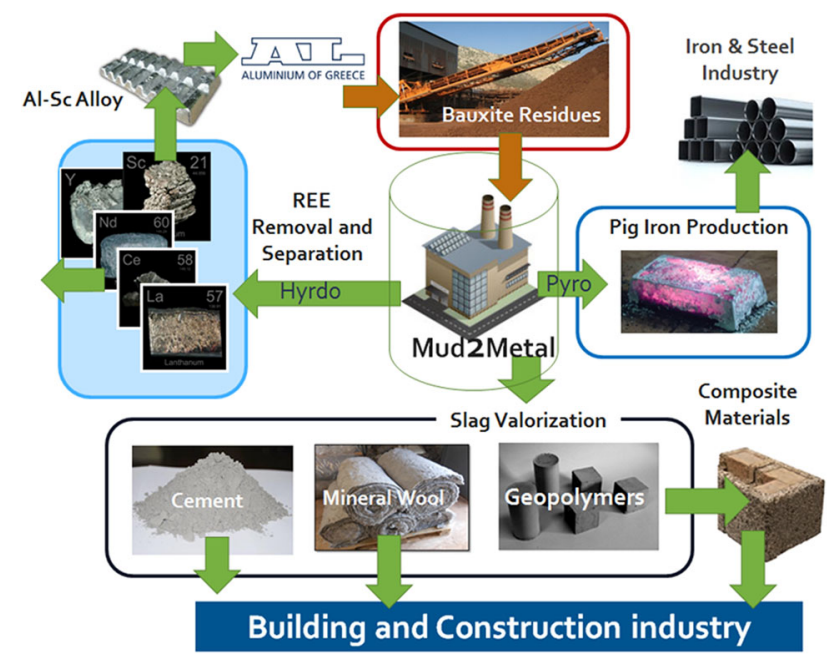

Fig. 8 Graphical representation of the Mud2Metal concept of industrial symbiosis

profitable for the industry given the high added value products emerging (Fig. 7).

Furthermore, should $\mathrm{Sc}_{2} \mathrm{O}_{3}$ be upgraded to Sc metal, then the latter could be combined with the aluminum metal product of the industry and produce the highest added value product possible from $\mathrm{BR}, \mathrm{Al}-\mathrm{Sc}$ master alloy. In such a case, the $136 \mathrm{t}$ of $\mathrm{Sc}_{2} \mathrm{O}_{3}$, contained within the annual BR production of AoG, would produce $4450 \mathrm{t}$ of Al-Sc master alloy ( $2 \mathrm{wt} \% \mathrm{Sc}$ ) the market price of which in 2013 was $150 \mathrm{EUR} / \mathrm{kg}$ (with large-scale production, one can expect the price of the alloy to reduce by the levels of 50-100 EUR/kg).

\section{Next Steps}

Figure 8 presents a graphical representation of the generalized concept. It is evident that the suggested process would lead to an industrial symbiosis scenario that is expected to stimulate economic growth. Obviously, each BR differs in chemical composition (especially more so, in trace elements like REE and Sc); therefore, the flow sheet presented here is not a universal solution. Furthermore, there are still technical, but predominantly non-technical, barriers, which need to be overcome before a lab-scale successful technology becomes an industrial reality. An overview of such challenges has been recently presented in detail elsewhere [7].

\section{Conclusions}

BR has been the biggest environmental issue of the alumina industry and is a field of intense scientific research to develop technologies that will allow its treatment. As focusing on a single application for the residue has failed to deliver a solution, the Mud2Metal concept proposes multiproduct valorization of the residue. The preliminary study presented here shows that the technology exists for a combined processing flow sheet which would result in nearly $100 \%$ BR utilization. In terms of economy, the iron and scandium content in the Greek BR seem to play the most crucial role in the process. Further development of added value products such as cast iron alloys, special cements, mineral wool, and $\mathrm{Al}-\mathrm{Sc}$ master alloys holds the key for increasing revenues from $\mathrm{BR}$, thus enabling a cost-effective and almost a zero-waste treatment.

Acknowledgements The research leading to these results has received funding from the European Community's Seventh Framework Programme ([FP7/2007-2013]) under Grant Agreements No. 309373 (EURARE www.eurare.eu) and No. 249710 (ENEXAL www. labmet.ntua.gr/enexal). This publication reflects only the authors' view, exempting the Community from any liability.

\section{References}

1. Balomenos E, Panias D, Paspaliaris I (2011) Energy and exergy analysis of the primary aluminum production processes: a review on current and future sustainability. Miner Process Extr Metall Rev 32(2):69-89

2. Klauber C, Gräfe M, Power G (2011) Bauxite residue issues: II. Options for residue utilization. Hydrometallurgy 108(1-2):11-32

3. Liu Z, Li H (2015) Metallurgical process for valuable elements recovery from red mud-a review. Hydrometallurgy 155:29-43

4. Borra CR et al (2016) Recovery of rare earths and other valuable metals from bauxite residue (red mud): a review. J Sustain Metall. doi:10.1007/s40831-016-0068-2

5. Pontikes Y, Angelopoulos GN (2013) Bauxite residue in cement and cementitious applications: current status and a possible way forward. Resour Conserv Recycl 73:53-63

6. Vangelatos I, Angelopoulos GN, Boufounos D (2009) Utilization of ferroalumina as raw material in the production of ordinary Portland cement. J Hazard Mater 168(1):473-478

7. Evans K (2016) The history, challenges, and new developments in the management and use of bauxite residue. J Sustain Metall. doi:10.1007/s40831-016-0060-x

8. Pontikes Y, Boufounos D, Angelopoulos GN (2011) Case studies for the valorisation of Bayer's process bauxite residue: aggregates, ceramics, glass-ceramics, cement and catalysis. In $2 \mathrm{nd}$ international slag valorisation symposium, Leuven

9. Wang W, Pranolo Y, Cheng CY (2011) Metallurgical processes for scandium recovery from various resources: a review. Hydrometallurgy 108(1-2):100-108

10. Krishnamurthy N, Gupta CK (2015) Resource processing, in extractive metallurgy of rare earths. CRC Press, Boca Raton, pp 235-332

11. Ochsenkühn-Petropoulou M, Tsakanika LA, Lymperopoulou T (2014) Process control of an innovative method for the recovery and separation of rare earths from red mud by different analytical techniques. In: ERES 2014-first European rare earth resources conference, Milos, Greece, 4-7 September 2014

12. Balomnenos E et al (2014) The ENEXAL bauxite residue treatment process: industrial scale pilot plant results. Light metals 2014. Wiley, Amsterdam, pp 141-147 
13. Binnemans $\mathrm{K}$ et al (2015) Towards zero-waste valorisation of rare-earth-containing industrial process residues: a critical review. J Clean Prod 99:17-38

14. Goodenough KM et al (2016) Europe's rare earth element resource potential: an overview of REE metallogenetic provinces and their geodynamic setting. Ore Geol Rev 72:838-856

15. Petrakova O, Klimentenok G, Panov A, Gorbachev S (2014) Application of modern methods for red mud processing to produce rare earth elements. In: Proceedings of the 1st European rare earth resources conference (ERES), Milos, pp 221-229

16. Binnemans $\mathrm{K}$ et al (2013) Recycling of rare earths: a critical review. J Clean Prod 51:1-22

17. ERECON (2015) Strengthening the European rare earths supply chain: challenges and policy options

18. European Commission (2014) Report of the Ad hoc working group on defining critical raw materials

19. Borra CR et al (2015) Leaching of rare earths from bauxite residue (red mud). Miner Eng 76:20-27

20. Davris $P$ et al (2016) Leaching rare earth elements from bauxite residue using Brønsted acidic ionic liquids A2 (Chap. 12). In: De Lima IB, Leal Filho W (eds) Rare earths industry. Elsevier, Amsterdam, pp 183-197

21. Ochsenkühn-Petropulu M, Lyberopulu T, Parissakis G (1994) Direct determination of landthanides, yttrium and scandium in bauxites and red mud from alumina production. Anal Chim Acta 296(3):305-313

22. U.S. Geological Survey (2016) Mineral commodity summaries. U.S. Geological Survey, Reston

23. Schlinkert D, van den Boogaart KG (2015) The development of the market for rare earth elements: insights from economic theory. Resour Policy 46:272-280

24. Golev A et al (2014) Rare earths supply chains: current status, constraints and opportunities. Resour Policy 41:52-59

25. www.institut-seltene-erden.org. Accessed on 1 Sept 2016

26. Ahmad Z (2003) The properties and application of scandiumreinforced aluminum. JOM 55(2):35-39

27. Boudghene Stambouli A, Traversa E (2002) Fuel cells, an alternative to standard sources of energy. Renew Sustain Energy Rev 6(3):295-304

28. Ciacchi FT, Badwal SPS, Drennan J (1991) The system $\mathrm{Y}_{2} \mathrm{O}_{3}-$ $\mathrm{Sc}_{2} \mathrm{O}_{3}-\mathrm{ZrO}_{2}$ : phase characterisation by XRD, TEM and optical microscopy. J Eur Ceram Soc 7(3):185-195

29. Borra CR et al (2016) Smelting of bauxite residue (red mud) in view of iron and selective rare earths recovery. J Sustain Metall 2(1):28-37

30. Ochsenkühn-Petropoulou MT et al (2002) Pilot-plant investigation of the leaching process for the recovery of scandium from red mud. Ind Eng Chem Res 41(23):5794-5801

31. Ochsenkühn-Petropulu M et al (1996) Recovery of lanthanides and yttrium from red mud by selective leaching. Anal Chim Acta 319(1-2):249-254

32. Smirnov DI, Molchanova TV (1997) The investigation of sulphuric acid sorption recovery of scandium and uranium from the red mud of alumina production. Hydrometallurgy 45(3):249-259

33. Wang W, Cheng CY (2011) Separation and purification of scandium by solvent extraction and related technologies: a review. J Chem Technol Biotechnol 86(10):1237-1246

34. Wang W, Pranolo Y, Cheng CY (2013) Recovery of scandium from synthetic red mud leach solutions by solvent extraction with D2EHPA. Sep Purif Technol 108:96-102

35. Fulford GD, Lever G, Sato T (1991) Recovery of rare earth elements from sulphurous acid solution by solvent extraction. US patent $5015447 \mathrm{~A}$
36. Yatsenko SP, Pyagai IN (2010) Red mud pulp carbonization with scandium extraction during alumina production. Theor Found Chem Eng 44(4):563-568

37. Qu Y, Lian B (2013) Bioleaching of rare earth and radioactive elements from red mud using Penicillium tricolor RM-10. Bioresour Technol 136:16-23

38. Davris P et al (2016) Selective leaching of rare earth elements from bauxite residue (red mud), using a functionalized hydrophobic ionic liquid. Hydrometallurgy 164:125-135

39. Ochsenkühn-Petropulu M, Lyberopulu T, Parissakis G (1995) Selective separation and determination of scandium from yttrium and lanthanides in red mud by a combined ion exchange/solvent extraction method. Anal Chim Acta 315(1-2):231-237

40. Balomenos E et al (2013) Resource-efficient and economically viable pyrometallurgical processing of industrial ferrous byproducts. Waste Biomass Valoriz 5(3):333-342

41. Paramguru RK, Rath PC, Misra VN (2004) Trends in red mud utilization - a review. Miner Process Extr Metall Rev 26(1):1-29

42. Kumar S, Kumar R, Bandopadhyay A (2006) Innovative methodologies for the utilisation of wastes from metallurgical and allied industries. Resour Conserv Recycl 48(4):301-314

43. Liu Y, Naidu R (2014) Hidden values in bauxite residue (red mud): recovery of metals. Waste Manag 34(12):2662-2673

44. Liu W, Yang J, Xiao B (2009) Application of Bayer red mud for iron recovery and building material production from alumosilicate residues. J Hazard Mater 161(1):474-478

45. Xenidis A et al (2011) Reductive smelting of Greek bauxite residues for iron production. In: Lindsay SJ (ed) Light Metals 2011. Wiley, Hoboken, pp 113-117

46. Zhu D-Q et al (2012) Recovery of iron from high-iron red mud by reduction roasting with adding sodium salt. J Iron Steel Res Int 19(8): $1-5$

47. Jayshankar K, Mukherjee PS, Bhoi B, Mishra CR (2013) Production of pig iron and Portland slag cement from red mud by application of Novel Thermal Plasma Technique, in Technical proceedings of IBAAS-CHALIECO 2013 international symposium. Nanning, Guangxi

48. Scrivener KL, Cabiron J-L, Letourneux R (1999) High-performance concretes from calcium aluminate cements. Cem Concr Res 29(8):1215-1223

49. Panias D, Giannopoulou I, Boufounos D (2014) Valorization of alumina red mud for production of geopolymeric bricks and tiles. In: Grandfield J (ed) Light Metals 2014. Wiley, Hoboken, pp 155-159

50. Papadopoulos AM (2005) State of the art in thermal insulation materials and aims for future developments. Energy Build 37(1):77-86

51. Provis JL, van Deventer JSJ (2009) Geopolymers, structures, processing, properties and industrial applications, 1st edn. Woodhead Publishing Ltd, Abingdon

52. He J et al (2013) Synthesis and characterization of red mud and rice husk ash-based geopolymer composites. Cement Concr Compos 37:108-118

53. Ke X et al (2015) One-part geopolymers based on thermally treated red mud/NAOH blends. J Am Ceram Soc 98(1):5-11

54. Ye N et al (2014) Synthesis and characterization of geopolymer from Bayer red mud with thermal pretreatment. J Am Ceram Soc 97(5):1652-1660

55. Hertel T, Blanpain B, Pontikes Y (2016) A proposal for a $100 \%$ use of bauxite residue towards inorganic polymer mortar. J Sustain Metall. doi:10.1007/s40831-016-0080-6

56. van Riessen A et al (2013) Bayer-geopolymers: an exploration of synergy between the alumina and geopolymer industries. Cement Concr Compos 41:29-33 